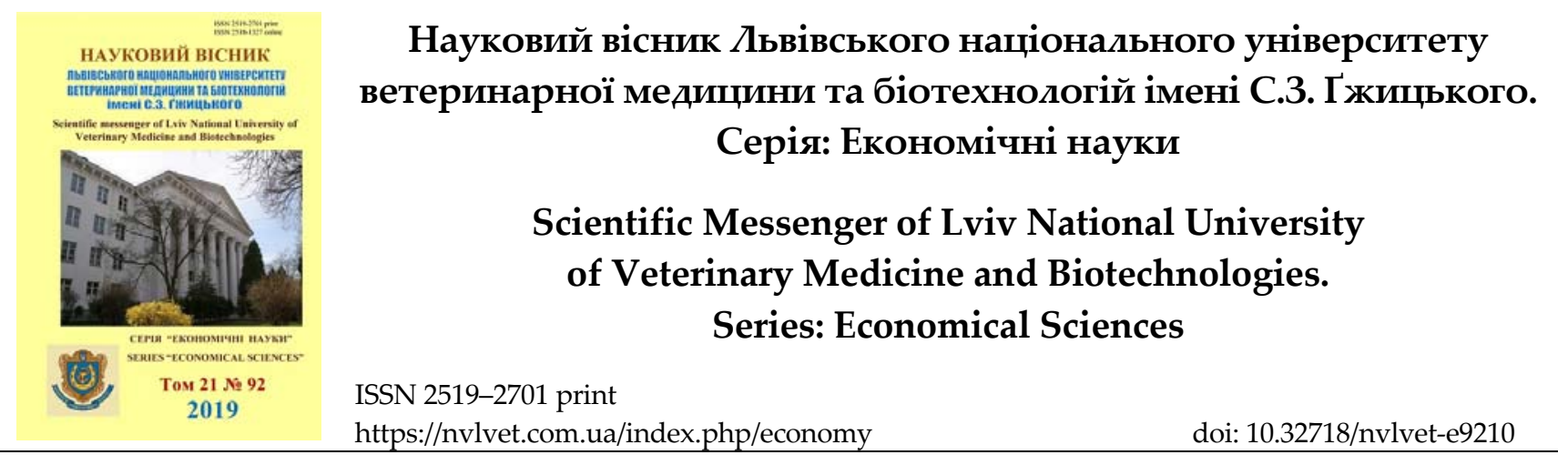

UDC 658.338.22:338.43.22

\title{
Ways of improvement of development of separate organizational and legal forms of entrepreneurship activity in the agricultural sector
}

I. Smolynets

Stepan Gzhytskyi National University of Veterinary Medicine and Biotechnologies Lviv, Ukraine

Article info

Received 22.01.2019

Received in revised form 25.02 .2019

Accepted 26.02.2019

Stepan Gzhytskyi National University of Veterinary Medicine and Biotechnologies Lviv,

Pekarska Str., 50, Lviv,

79010, Ukraine.

Tel.: +38-067-977-78-01

E-mail:smolinecz86@ukr.net
Smolynets, I. (2019). Ways of improvement of development of separate organizational and legal forms of entrepreneurship activity in the agricultural sector. Scientific Messenger of Lviv National University of Veterinary Medicine and Biotechnologies. Series: Economical Sciences, 21(92), 6067. doi: $10.32718 /$ nvlvet-e9210

One of the most important directions in this context is the problems of organizational and legal forms of development of entrepreneurial activity in agriculture. Effective development of entrepreneurial activity in agriculture is hindered by poor adaptation to market conditions and low investment attractiveness of agrarian production and economic formations, unsystematic and dispersed revenues for modernization of production activities, insufficient state support, imperfection of the organizational and economic mechanism for managing the development of various organizational and legal forms of entrepreneurial activity activities in the agrarian sector. In the historical aspect of the development of entrepreneurial activity there are the following forms: private farms, individual holdings, households, peasant farms, private and state agricultural enterprises, collective farms, in particular peasant unions, agricultural companies, inter-farm enterprises and associations, of various kinds and types societies that are divided in form of association and level of responsibility. The most important of these, which have become accustomed and function in agriculture, are agricultural enterprises, in particular private ones, and households. However, today the state of development of entrepreneurial activity in the agroindustrial complex remains rather complicated and requires complex comprehensive reforms, the main role of which should be owned by the state. That is why among the objects of state regulation a special place should occupy the agrarian sector of the economy and the forms of entrepreneurial activity, in particular the agrarian market and the formation of its infrastructure, which is conditioned by the state regulation. The main problems of the agrarian sector development include the low efficiency of agricultural production and the problem of deformation of price proportions, the solution of which is directly related to the perfection of the infrastructure and mechanisms for regulating the agricultural market. The process of establishing enterprises on the basis of co-operation and their integration with processing enterprises will reflect the interests of agricultural producers and promote their stable and efficient development. The most effective form of co-operation is production, sales and service cooperatives, created on the basis of cooperation of shares and natural forage lands, fixed assets, livestock of animals that unite agricultural producers, households, purchasers, enterprises of the processing industry, various catering enterprises, institutions and organizations. Co-operation, by its very nature, is an economic and voluntary phenomenon. Integration is the next stage of effective economic forms of cooperation among the participants in the agrarian market.

Key words: agriculture, entrepreneurial activity, agrarian production, market, aspects of development of organizational and legal forms of entrepreneurial activity, agrarian sector of economy.

\section{Шляхи удосконалення розвитку окремих організаційно-правових форм підриємницької діяльності в аграрному секторі}

\author{
І.Б. Смолинець
}

Львівський національний університет ветеринарної медицини та біотехнологій імені С.3. Гжицького, м. Львів, Украӥна 
Одним з найважливіших напрямів в цььому контексті є проблеми організаційно-правових форм розвитку підприємницької діяльності в сільському господарстві. Ефективному розвитку підприємницької діяльності в сільському господарстві перешкоджають слабка адаптація до ринкових умов та низька інвестиційна привабливість аграрного виробництва і господарських формувань, безсистемність і розпорошеність надходжень коштів у модернізацію виробничої діяльності, недостатня державна підтримка, недосконалість організачійно-економічного механізму управління розвитком різних організаційно-правових форм підприємницької діяльності в аграрному секторі. В історичному аспекті розвитку підприємницька діяльність налічує такі форми: приватні підсобні господарства, одноосібні володіння, господарства населення, селянські фермерські господарства, приватні та державні сільськогосподарські підприємства, колективні господарства, зокрема селянські спілки, агрофірми, міжгосподарські підприємства $і$ об'єднання, різного роду та видів товариства, які поділяються за формою об'єднання та рівнем відповідальності. Найважливіші з них, які прижились та функиіонують в сільському господарстві, є сільськогосподарські підприємства, зокрема приватні, та господарства населення. Однак сьогодні стан розвитку підприємницької діяльності в АПК залишається достатньо складним та вимагає здійснення комплексних масштабних реформ, головна роль при проведенні яких має належати державі. Саме тому серед об'єктів державного регулювання особливе місче повинен займати аграрний сектор економіки та форми підприємницької діяльності, зокрема аграрний ринок та формування його інфраструктури, щзо обумовлюється державним регулюванням останнього. До основних проблем розвитку аграрного сектора необхідно віднести низьку ефективність сільськогосподарського виробниитва та проблему деформації ичінових пропориій, вирішення яких безпосередньо пов'язане із досконалістю інфраструктури та механізмів регулювання кон'юнктури аграрного ринку. Створення підприємств на основі кооперування та їх інтеграиії із переробними підприємствами буде відображати інтереси сільськогосподарських товаровиробників і сприяти їхньому стабільному та ефективному розвитку. Найефективнішою формою кооперації є виробничі, збутові та обслуговуючі кооперативи, створені на основі кооперації паїв та природних кормових угідь, основних засобів, поголів'я тварин, які об'єднують виробників сільськогосподарської продукції, господарства населення, заготівельників, підприємства переробної промисловості, різні обслуговуючі підприємства, установи та організачї. Кооперачія, за своєю суттю - явище економічне і добровільне. Інтеграція є наступним етапом ефективних економічних форм співпрачі учасників аграрного ринку.

Ключові слова: сільське господарство, підприємницька діяльність, аграрне виробництво, ринок, аспекти розвитку організаиійно-правових форм підприємницької діяльності, аграрний сектор економіки.

\section{Вступ}

Удосконалення щодо оцінки ефективності підприємницької діяльності окремих організаційно-правових форм в сільському господарстві, які передбачають порівняння показників ефективності (продуктивності праці, урожайності культур, продуктивності тварин, вартості виробленої продукції з розрахунку на 1 га сільськогосподарських угідь, норм прибутку, рентабельності виробництва), але з урахуванням впливу таких чинників, як рівень концентрації виробництва, форма власності на засоби виробництва й спосіб іï використання, характеристика сильних і слабких сторін порівнюваних господарських формувань, які дадуть можливість визначити 3 них найефективніші і найперспективніші (Andriichuk, 2005; Amosov, 2008).

Mета статті: шляхи удосконалення розвитку окремих організаційно-правових форм підприємницької діяльності в аграрному секторі, форми власності на засоби виробництва й способи іiї використання, характеристика сильних і слабких сторін порівнюваних господарських формувань. Все це в комплексі дозволить визначити з них найефективніші і найперспективніші. Нами використані традиційні методи та підходи економічного аналізу, зроблено посилання на власні публікації, де висвітлено окремі аспекти та результати дослідження.

\section{Результати та їх обговорення}

Сільськогосподарське виробництво в економіці будь-якої держави займає особливе місце. Основним завданням підприємницької діяльності в сільському господарстві $€$ забезпечення населення продуктами харчування в необхідній кількості та якості, формування певного рівня цін на продовольчі товари, при якому вони були б доступними для всіх рівнів населення та одночасно забезпечували б певний рівень прибутковості виробникам, гарантування зайнятим у сільськогосподарськім виробництві працівникам доходів, прирівняних до доходів працівників інших галузей економіки. Рівень розвитку сільськогосподарського виробництва визначає рівень економічної безпеки країни та основної іії складової - продовольчої безпеки.

Сільська місцевість і підприємницька діяльність в аграрній сфері тісно пов'язані між собою. Сільськогосподарське виробництво $є$ провідною галуззю матеріального виробництва в сільській місцевості й повинно, з одного боку, сприяти збільшенню виробництва сільськогосподарської продукції, а з іншого - забезпечити населення умовами праці, побуту і відпочинку (Berezivskyi, 1999).

Впродовж багатьох років аграрне виробництво у Львівській області розвивалось стабільними темпами та забезпечувало населення області продуктами власного виробництва, а промисловість - сировиною. Цінові пропорції певною мірою дозволяли виробникам сільськогосподарської продукції вести високорентабельне виробництво та розширене відтворення. Починаючи з 1991 року сільськогосподарське виробництво почало занепадати, основними причинами чого стала відсутність обгрунтованої програми переходу аграрного сектору до ринкових відносин, порушення паритету цін на сільськогосподарську та промислову продукцію, недосконалий механізм кредитування, недостатній захист товаровиробників 3 боку держави тощо. Незважаючи на зростання валового виробництва сільськогосподарської продукції в Львівській області (за рахунок іiі окремих видів), на даний час підприємницька діяльність в аграрній сфері переживає складний період свого розвитку, зокрема в питаннях фінансового забезпечення та економічної ефективності. Внаслідок непослідовності та безсистемності проведення аграрних реформ в Україні, зниження платоспроможного попиту населення, порушення диспаритету цін на сільськогосподарську продукцію і матеріально-технічні ресурси для села, недо- 
сконалості законодавчої бази і недостатньої державної підтримки діюча система виробництва та реалізації продукції не відповідає вимогам ринкової економіки і одночасно з ускладненням взаємовідносин між сільськогосподарськими товаровиробниками і зокрема переробними підприємствами призвели до погіршення економічних показників сільськогосподарських виробників (Bitter et al., 1997; Berezin, 2012; Smolynets, 2014).

За досліджуваний період відбулися структурні зміни земельних угідь, зокрема сільськогосподарських, за категоріями господарств Львівської області. Так, питома вага сільськогосподарських угідь в аграрних підприємствах в 2016 році зменшилась порівняно із 2000 роком на $11,4 \%$, рілля на $17,3 \%$. С в області площі земель сільськогосподарського призначення, що не розорані, пустують і заростають бур'янами. Зменшилася чисельність поголів'я тварин в сільськогосподарських підприємствах, зокрема великої рогатої худоби та корів. В індивідуальних господарствах населення, де вироблено 70\% валової продукції сільського господарства, не можливо в умовах дрібного товарного виробництва запровадити племінну репродуктивну справу в галузі тваринництва, вести селекцію галузі рослинництва із застосуванням сівозмін та на їх основі виробити якісну продукцію. Тому основна увага повинна бути зосереджена на розширенні виробництва в агроформуваннях, де можна забезпечити дотримання певних вимог ведення господарства та якості сировини і досягти прибутковості сільськогосподарської галузі (Yermakov, 2003; Onyshchenko, 2004; Smolynets, 2013).

Підприємницька діяльність в сільському господарстві може розвиватись в ринкових умовах тільки за певної концентрації виробництва та впровадження інновацій. Так, наприклад, для його розвитку необхідне спрямування зусиль на відновлення поголів'я, чисельність якого постійно скорочується, забезпечення племінних якостей основного стада, що вплинуло б на підвищення продуктивності та збільшення виробництва тваринницької продукції. Доведення поголів’я тварин до необхідної кількості дуже важливе, адже матеріально-технічні можливості багатьох підприємств на сьогодні ще дозволяють це зробити. Оскільки невелике за обсягом сільськогосподарське виробництво не дозволяє повною мірою використовувати технічні засоби, стає неокупним та не дозволяє впроваджувати сучасні технології виробництва екологічно чистої продукції. Тому дуже важливим у розвитку підприємницької діяльності є формування нових ефективних організаційно-правових форм в сільському господарстві, які б вплинули на підвищення економічної ефективності аграрного виробництва (Shmorhun, 1999; Sabluk, 2000).

Для моделювання ефективних форм підприємницької діяльності в сільському господарстві детальніші розрахунки проведемо на прикладі виробництва продукції свинарства (виробництво приросту свиней в живій масі), так як дослідження засвідчують - зростання свинопоголів'я в сільськогосподарських підприємствах за 12 років на 108,1 тис. гол., або в 6,4 рази.

Як показують дані таблиці 1, в 2016 році виробництво приросту свинини в живій масі в сільськогосподарських підприємствах дещо збільшилось порівняно iз 2015 роком - на 18475 ц, або на 13,1\%. Основна питома вага приросту свинини в живій масі вирощується не в державних сільськогосподарських підприємствах, зокрема в господарських товариствах -понад 96\%. Аналіз економічних показників доводить, що, незважаючи на таке зростання свинопоголів'я в динаміці та збільшення виробництва приросту свинини в живій масі, результати підприємницької діяльності в даній галузі за 2015 рік були збитковими. Із 41 сільськогосподарського підприємства, 25, тобто більше половини, що займалися вирощуванням свинини, мали збитки. Із 18 господарських товариств в 11-ти вирощування свинини було збитковим.

Дещо краща ситуація в 2016 році. Рівень рентабельності вирощування приросту свинини в живій масі становив $8,1 \%$, господарські товариства одержали 19708,3 тис. грн. прибутку, або в розрахунку на 1 ц він становив 128,02 грн. Проте ситуація тут виглядає парадоксальною. Як доводять дослідження, при різкому збільшенню поголів'я свиней та об'ємів вирощування свинини в живій масі у сільськогосподарських підприємствах результат від такої діяльності у них збитковий. Причин декілька. Однією 3 них може бути не об'єктивність надання статистичної звітності про фактичні економічні показники діяльності суб'єктами господарювання. Другим важливим фактором, що мав вплив на економічні результати вирощування свинини, були низькі закупівельні ціни.

Для більш детального з'ясування стану такої низької ефективності вирощування приросту свинини в живій масі у сільськогосподарських підприємствах проведемо порівняння їхніх економічних показників, в тому числі господарських товариств із підприємствами, що спеціалізуються на забої свиней та реалізації м'яса свинини (табл. 2).

Із даних таблиці видно, що ціни реалізації м'яса свинини перевищують його собівартість та забезпечують переробним підприємствам відповідний дохід та рентабельність. Так, в 2016 році кожен центнер реалізованої свинини в забійній вазі приніс досліджуваним переробним підприємствам в середньому 631 грн доходу, що забезпечило їм 21,7\% рентабельності виробництва. Заклади торгівлі одержали в середньому від реалізованого 1ц м'яса свинини 347 грн доходу, забезпечивши рентабельність 9,4\%, що на 230 грн більше, ніж одержали доходу за кожен центнер вирощеної свинини сільськогосподарські підприємства. 
Таблиця 1

Економічні показники вирощування свиней на м’ясо (в живій масі) у Львівській області

\begin{tabular}{|c|c|c|c|c|c|c|c|c|c|c|}
\hline \multirow[b]{3}{*}{$\begin{array}{c}\text { Сільськогоспо-дарські } \\
\text { підприємства за організа- } \\
\text { ційно-правовими форма- } \\
\text { ми підприємницької } \\
\text { діяльності }\end{array}$} & \multicolumn{8}{|c|}{ Результати від реалізації свиней на м’ясо (в живій масі) } & \multirow{2}{*}{\multicolumn{2}{|c|}{$\begin{array}{c}\begin{array}{c}\text { кількість } \\
\text { господарств }\end{array} \\
\end{array}$}} \\
\hline & \multicolumn{5}{|c|}{ Всього } & \multicolumn{3}{|c|}{1 центнера, грн. } & & \\
\hline & $\begin{array}{l}\text { кіль- } \\
\text { кість } \\
\text { продук- } \\
\text { ції в } \\
\text { живій } \\
\text { масі, ц }\end{array}$ & $\begin{array}{c}\text { вироб- } \\
\text { нича } \\
\text { собівар- } \\
\text { тість } \\
\text { продук- } \\
\text { ції, тис. } \\
\text { грн. }\end{array}$ & $\begin{array}{l}\text { повна } \\
\text { собівар- } \\
\text { тість } \\
\text { продукції, } \\
\text { тис. грн. }\end{array}$ & $\begin{array}{c}\text { чистий } \\
\text { дохід } \\
\text { (виручка), } \\
\text { тис. грн. }\end{array}$ & $\begin{array}{c}\text { прибу- } \\
\text { ток } \\
\text { (збиток), } \\
\text { тис. грн. }\end{array}$ & $\begin{array}{c}\text { повна } \\
\text { собівар- } \\
\text { тість }\end{array}$ & $\begin{array}{c}\text { ціна } \\
\text { реаліза- } \\
\text { ції }\end{array}$ & $\begin{array}{l}\text { рівень } \\
\text { рента- } \\
\text { бельно- } \\
\text { сті } \\
\text { (збитко- } \\
\text { вості), \% }\end{array}$ & всього & $\begin{array}{c}\text { у тому } \\
\text { числі які } \\
\text { одержа- } \\
\text { ли } \\
\text { збитки }\end{array}$ \\
\hline \multicolumn{11}{|c|}{2015 рік } \\
\hline Господарські товариства & 135537 & 225823 & 252163 & 233057 & -19106 & 1860,47 & 1719,5 & $-7,6$ & 18 & 11 \\
\hline Приватні підприємства & 5150 & 7576 & 8242 & 7718 & -524 & 1600,41 & 1498,5 & $-6,4$ & 20 & 12 \\
\hline $\begin{array}{l}3 \text { них селянські (фермер- } \\
\text { ські) господарства }\end{array}$ & 69 & 93 & 102 & 96 & -6 & 1472,46 & 1386,9 & $-5,8$ & 1 & 1 \\
\hline Сільгоспкооперативи & 94 & 128 & 136 & 135 & -1 & 1447,87 & 1436,1 & $-0,8$ & 2 & 1 \\
\hline Недержавні підприємства & 140781 & 233527 & 260541 & 240909 & -19632 & 1850,68 & 1711,2 & $-7,5$ & 40 & 24 \\
\hline Державні підприємства & 18 & 47 & 57 & 24 & -33 & 3144,44 & 1333,3 & $-57,6$ & 1 & 1 \\
\hline $\begin{array}{l}\text { Сільськогосподарські } \\
\text { підприємства }\end{array}$ & 140799 & 233574 & 260598 & 240933 & -19664 & 1850,85 & 1711,1 & $-7,6$ & 41 & 25 \\
\hline \multicolumn{11}{|c|}{2016 рік } \\
\hline Господарські товариства & 153942 & 154306 & 242898 & 262606 & 19708 & 1577,85 & 1705,8 & 8,1 & 16 & 8 \\
\hline Приватні підприємства & 5310 & 8490 & 9225 & 8070 & -1155 & 1737,29 & 1519,8 & $-12,5$ & 14 & 10 \\
\hline $\begin{array}{l}3 \text { них селянські (фермер- } \\
\text { ські) господарства }\end{array}$ & 518 & 765 & 840 & 788 & -52 & 1621,62 & 1521,4 & $-6,2$ & 1 & 1 \\
\hline Сільгоспкоопе-ративи & 3 & 15 & 16 & 8 & -8 & 5333,33 & 2666,6 & $-50,0$ & 1 & 1 \\
\hline Недержавні підприємства & 159255 & 162811 & 252139 & 270684 & 18546 & 1583,24 & 1699,6 & 7,4 & 31 & 19 \\
\hline Державні підприємства & 19 & 49 & 60 & 27 & -33 & 3157,89 & 1421,0 & $-55,0$ & 1 & 1 \\
\hline $\begin{array}{l}\text { Сільськогоспо-дарські } \\
\text { підприємства }\end{array}$ & 159274 & 162860 & 252199 & 270711 & 18513 & 1583,43 & 1699,6 & 7,3 & 32 & 20 \\
\hline
\end{tabular}

Таблиця 2

Результати від реалізації свинини в підприємствах Львівської області, 2016 рік

\begin{tabular}{|c|c|c|c|c|}
\hline \multirow{2}{*}{ Підприємства } & \multicolumn{3}{|c|}{1 центнер, грн } & \multirow{2}{*}{$\begin{array}{c}\text { Рівень } \\
\text { рентабельності, \% }\end{array}$} \\
\hline & Повна собівартість & Ціна реалізації & Прибуток & \\
\hline $\begin{array}{l}\text { Сільськогосподарські підприємства, } \\
\text { всього (жива вага) }\end{array}$ & 1583 & 1700 & 117 & 7,3 \\
\hline $\begin{array}{l}\text { в т. ч. господарські товариства } \\
\text { (жива вага) }\end{array}$ & 1578 & 1706 & 128 & 8,1 \\
\hline Переробні під-приємства (забійна вага) & $2912 *$ & 3543 & 631 & 21,7 \\
\hline Заклади торгівлі (забійна вага) & 3703 & 4050 & 347 & 9,4 \\
\hline
\end{tabular}

Джерело: розрахунки власні на підставі [ даних Головного управління статистики у Львівській області]

*Враховано, коефіцієнт переводу живої маси свинини в забійну 0,70

Проведений аналіз доводить, що основна питома вага доходу від виробництва свинини, іiі переробки та реалізації осідає в переробних підприємствах та частково в закладах торгівлі.

Як свідчать наведені показники таблиці 2, навіть заклади торгівлі одержали більше доходу на кожному реалізованому центнері свинини та вищу рентабельність, ніж безпосередні їі виробники.

Сфера виробництва сільськогосподарської сировини за своєю природою завжди є найбільш складною, матеріало - та трудомісткою. Вкладення коштів в переробну промисловість $є$ менш ризиковане й забезпечує більший прибуток, ніж підприємницька діяльність в сільськогосподарському виробництві. Торгівля готовими продуктами забезпечує найшвидший кругообіг коштів і найбільшу віддачу вкладень у цю сферу порівняно з попередніми. Така закономірність є однією з об'єктивних передумов диспаритету цін, і якщо виробник сільськогосподарської сировини не знаходить способу скористатися вигодами інших сфер такого бізнесу, він не може розраховувати на успішну підприємницьку діяльність за умов ринку.

Враховуючи повну собівартість 1 ц свинини в закладі реалізації - 3703 грн в 2016 році, можна визначити питому вагу витрат кожної складової ланки маркетингового ланцюга “виробництво-переробкаторгівля готової продукції”. При розрахунках необхідно врахувати той факт, що при забої свиней в середньому вихід забійної ваги становить 70\% від живої.

Із даних таблиці 3 видно, що найбільшу питому вагу у витратах займають витрати сільськогосподарських підприємств на вирощування свиней $-77,9 \%$. Другу позицію займають витрати переробних підприємств - 16,6\% на забій та переробку. I найменше витрат несуть торгівельні підприємства - 160 грн. на одному центнері, або 5,5\%. 
Таблищя 3

Структура витрат на виробництво, переробку та реалізацію свинини та розподіл прибутку

\begin{tabular}{lccccc}
\hline \multicolumn{1}{c}{ Підприємства } & $\begin{array}{c}\text { Витрати } \\
\text { на 1 ц, } \\
\text { грн }\end{array}$ & $\begin{array}{c}\text { Структура } \\
\text { витрат, \% }\end{array}$ & $\begin{array}{c}\text { Прибуток } \\
\text { на 1 ц, } \\
\text { грн }\end{array}$ & $\begin{array}{c}\text { Структура розпо- } \\
\text { ділу } \\
\text { прибутку } \\
\text { (пропонована), \% }\end{array}$ & $\begin{array}{c}\text { Різниця прибутку при врахуванні } \\
\text { його розподілу пропорційно поне- } \\
\text { сеним витратам в порівнянні із } \\
\text { фактнодержаним в 2013 році }\end{array}$ \\
\hline $\begin{array}{l}\text { Сільськогосподарські підпри- } \\
\text { ємства, всього (жива вага) }\end{array}$ & $2264^{*}$ & 77,9 & 892 & 77,9 & +775 \\
$\begin{array}{l}\text { Переробні підприємства } \\
\text { (забійна вага) }\end{array}$ & 481 & 16,6 & 190 & 16,6 & -441 \\
Заклади торгівлі (забійна вага) & 160 & 5,5 & 63 & 5,5 & -284 \\
$\begin{array}{l}\text { Разом по цілому ланцюгу } \\
\text { виробничого процесу }\end{array}$ & 2905 & 100,0 & $1145^{* *}$ & 100,0 & $\mathrm{X}$ \\
\hline
\end{tabular}

Побудовано автором на основі розрахунків додатку Д

* Враховано 1,43ц живої маси свинини (при коефіцієнті переводу живої маси в забійну 0,70 )

** Розраховано при ціні реалізації 1ц (забійна вага) свинини 4050 грн.

Згідно зі встановленим співвідношенням витрат ми пропонуємо і розподіляти весь дохід, який буде одержаний від реалізації готової продукції, тобто за формулою одержання доходу пропорційно понесеним витратам на кожній стадії просування продукції. Із порівняння розподіленого прибутку між учасниками виробничого процесу від вирощування свинини до реалізації готової продукції пропорційно понесеним витратам до фактично одержаного прибутку в 2016 році випливає, що сільськогосподарські підприємства одержали б на 775 грн більше прибутку за кожен 1ц вирощеної свинини ніж це є фактично, забезпечивши при такому доході 39,4\% рентабельності.

3 метою забезпечення функціонування такого економічного механізму пропонуємо створення інтегрованих підприємств на основі кооперації, які би забезпечили високу ефективність на кожній стадії відтворювального процесу. Конкурентоспроможність сільськогосподарських товаровиробників в умовах ринкових відносин залежить не тільки від успішної організації виробництва, а й значною мірою - від його участі в наступних за виробництвом сферах діяльності та просування продукції.

Враховуючи взаємопов'язаність між собою учасників ринку такої продукції, однакову кінцеву мету їхньої підприємницької діяльності, необхідний пошук взаємовигідних форм поєднання їх співпраці, які б могли при можливості уникати вище перелічених ризиків та запобігати їм у аграрному виробництві, бути більш ефективними, поліпшити фінансове забезпечення агровиробників, їх економічні взаємовідносини, зокрема таких як кооперація та інтеграція. I це має бути предметом відповідної стратегії розвитку підприємницької діяльності в сільському господарстві.

Створення підприємств на основі кооперування та їх інтеграції і з переробними підприємствами буде відображати інтереси сільськогосподарських товаровиробників і сприяти їх стабільному та ефективному розвитку. Найефективнішою формою кооперації $\epsilon$ виробничі, збутові та обслуговуючі кооперативи, створені на основі кооперації паїв та природних кормових угідь, основних засобів, поголів'я тварин, які об'єднують виробників сільськогосподарської продукції, господарства населення, заготівельників, підприємства переробної промисловості, різні обслуговуючі підприємства, установи та організації. Кооперація, за своєю суттю, явище економічне і добровільне. Інтеграція $є$ наступним етапом ефективних економічних форм співпраці учасників аграрного ринку.

Насамперед пропонується створити на базі та за ініціативою виробників свинини виробничі кооперативи, куди ввійшли б сільськогосподарські підприємства, господарські товариства та інші організаційноправові форми підприємницької діяльності в цій галу3і. Створені на базі та за ініціативою сільськогосподарських підприємств такі кооперативні формування покликані забезпечити одержання вигод виробникам свинини і від суміжних сфер агробізнесу.

Окрім того, передбачається створення обслуговуючих та заготівельних кооперативів, кооперативу 3 виробництва та постачання кормів. Обслуговуючі кооперативи повинні забезпечити виробників свинини 3 ветеринарного обслуговування i матеріальнотехнічного постачання за мінімальними цінами, які значно нижчі за ціни ринкових посередників, проведення ремонтних робіт та надання інших послуг. Заготівельні кооперативи будуть займатися заготівлею вирощеної свинини в населення та фермерських господарств.

Такі кооперативи повинні стати дієвим засобом захисту товаровиробників в умовах ринкового середовища, використовуючи вигоди прибуткових галузей, зокрема переробних підприємств та торгових, акумулюючи таким чином значні кошти, необхідні для розвитку ефективного виробництва.

Найбільш успішним способом адаптації таких сільськогосподарських виробничих кооперативів та інших сільськогосподарських товаровиробників до ринкового середовища $є$ об'єднання їх на основі вертикальної інтеграції з переробними підприємствами та створення ними інтегрованих формувань. Товаровиробник, який займається вирощуванням свиней, може стати членом інтегрованого кооперативного об'єднання 3 тим, щоб продавати не сировину, а готові м'ясні вироби і мати від цього більший прибуток. Для прикладу 3 метою забезпечення ефективності вирощування свинини нами запропоновано створення такого інтегрованого підприємства в Пустомитівському районі Львівської області (рис. 1). Організаційну структуру районного інтегрованого формування утво- 
рюють виробничі, заготівельні та обслуговуючі кооперативи, підприємства із забою свиней та підприємства 3 переробки свинини і виробництва 3 неї готової продукції, заклади оптової та фірмової торгівлі.

Мета інтегрованого підприємства насамперед збільшення доходності членів виробничого кооперативу та членів сільських заготівельних кооперативів за рахунок отримання вищої ціни за одиницю переробленої та реалізованої через таке підприємство свинини та готової продукції, що досягається за рахунок того, що воно має змогу сформувати великі об'єми свинини, переробити та реалізувати в центрах фірмової та оптової торгівлі.

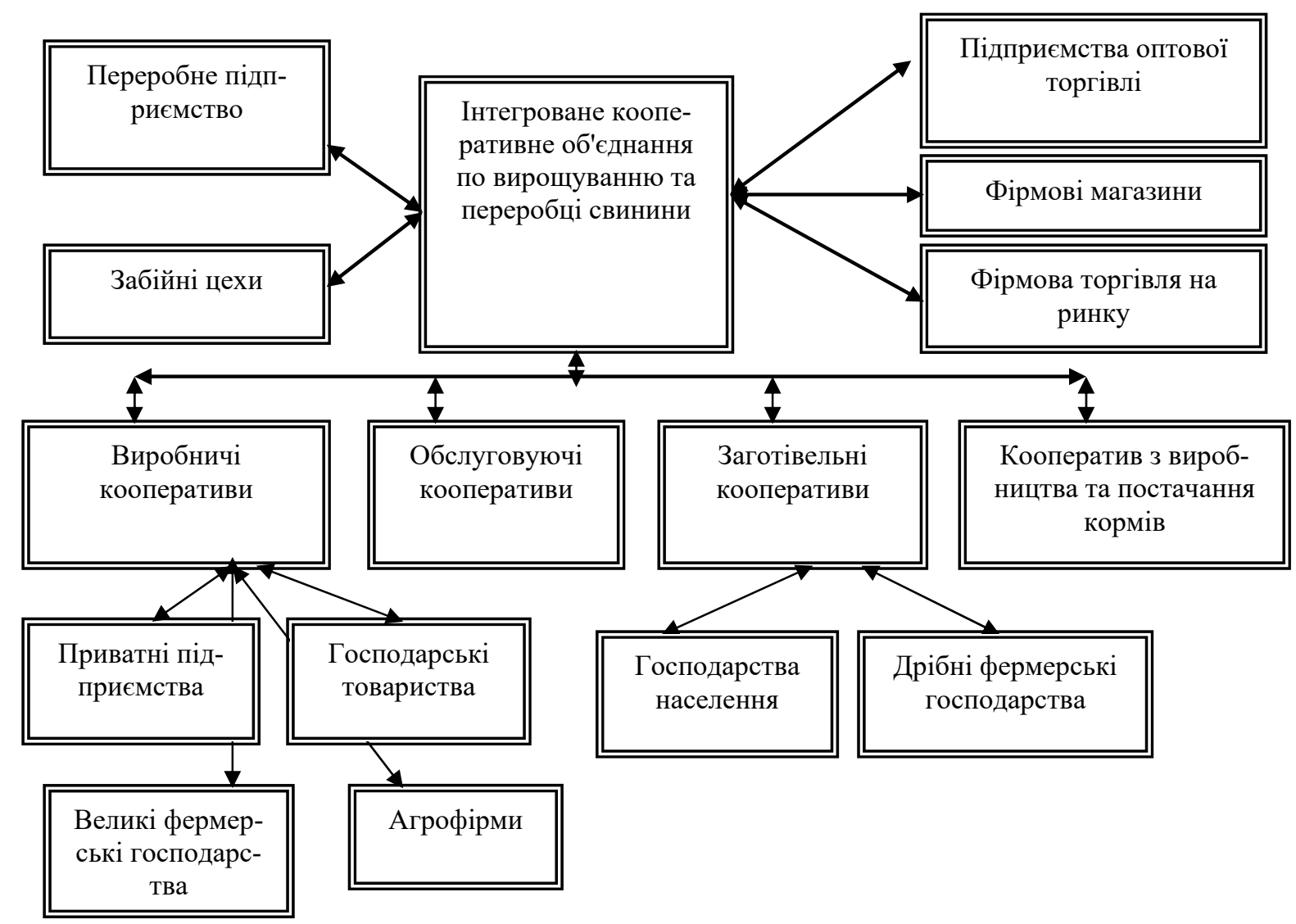

Рис. 1. Організаційна структура районного інтегрованого підприємства з вирощування та переробки свинини на основі кооперації

В інтегрованому кооперативному об’єднанні з вирощування та переробки свинини під час укладання договору із виробничими та заготівельними кооперативами на постачання та збут свинини встановлюють попередні ціни, які включають орієнтовану собівартість вирощування 1ц живої маси. Через те, що собівартість продукції може бути підрахована лише після закінчення фінансового року, ціноутворення в кооперативі, що збуває продукцію своїх членів, складається з двох частин:

- на початку сезону членам кооперативне об'єднання встановлює попередні ціни, які авансуються у виробництво свинини;

- кінцева ціна, яку виробник отримує за вирощену свинину (попередня ціна + кооперативні виплати) дорівнює собівартості.

Окрім того, наприкінці фінансового року фінансовий результат (прибуток) діяльності інтегрованого кооперативного об'єднання розподіляється серед членів у вигляді кооперативних доплат, які додаються до попередніх цін, що були виплачені їм за продукцію (надбавки), пропорційно понесеним витратам. Доплати підраховуються лише наприкінці року і залежить від результатів спільної діяльності членів такого кооперативного об'єднання.

За своєю суттю такий вид вертикальної інтеграції являє собою об'єднання зусиль товаровиробників 3 вирощування свинини і переробників з метою просування у суміжні із сільськогосподарським виробництвом сфери діяльності для забезпечення контролю за рухом створеної у власному виробництві продукції та одержання від цього оптимального прибутку. Досвід розвинутих країн засвідчує, що вертикальна інтеграція товаровиробників на основі їх групових дій має позитивне значення. Дані інтегровані угруповання покликані захистити інтереси сільськогосподарських товаровиробників у ринкових умовах, стати альтернативним шляхом розв'язання проблеми засилля посередницьких структур в агробізнесі та максимально підвищити їх ефективність і прибутковість.

Тільки за таких умов можливе успішне функціонування виробничих кооперативів у ринкових умовах. Тому кожен керівник сільськогосподарського підприємства повинен визначити для себе пріоритети успішного функціонування його підприємницької діяльності, і якщо виробництво сировини не забезпечує необ- 
хідного рівня рентабельності, робити все для того, щоб брати участь у подальшому русі виробленої продукції до кінцевого споживача, забезпечуючи таким чином стабільне одержання відповідного прибутку від переробки та реалізації продукції.

Стратегія подальшого розвитку підприємницької діяльності в сільському господарстві повинна бути спрямована на поліпшення санітарно-гігієнічної i оздоровчої якості сировини та сільськогосподарської продукції; підвищення конкурентоздатності і рентабельності аграрних підприємств; забезпечення сучасного технологічно-розвинутого сільськогосподарського виробництва з урахуванням міжнародних стандартів, що забезпечило б розширення експорту продуктів українського виробника на зовнішній ринок та пошук нових ринків збуту. Для цього повинна бути розроблена державна програма дій в сфері виробництва і формування сировинної бази, в галузі переробки продукції і маркетингу та підкріплена відповідними фінансовими засобами для реалізації.

Тому необхідність поглибленого наукового розроблення питань формування сільськогосподарських інтегрованих формувань на основі кооперації, їх інвестиційного забезпечення мають дуже важливе значення в розвитку підприємницької діяльності, особливо в сільському господарстві.

Враховуючи складний фінансовий стан більшості підприємств - виробників сільськогосподарської продукції, особливо аграрної сфери, в сучасних умовах доцільним $є$ залучення іноземних інвестицій. Підвищенню ефективності використання таких іноземних інвестицій сприяє в даному випадку створення спільних підприємств, сформованих аграрними виробниками, підприємствами 3 промислової переробки та реалізації готової продукції за участю іноземних фірм і компаній. Створення спільних підприємств дає можливість використовувати високопродуктивну техніку вітчизняних та зарубіжних виробників, застосовувати нові прогресивні ресурсозберігаючі технології. За рахунок цього досягається певне підвищення продуктивності праці та поліпшуються якісні характеристики сільськогосподарської продукції. Своєчасне над- ходження валютної виручки гарантує відповідне матеріально-технічне і фінансове обслуговування виробничого процесу та поповнення оборотних засобів.

До пріоритетних для інвестування галузей, які спроможні в стислий строк накопичувати інвестиційні ресурси, належать ті, що оперативно реагують на зростання споживчого попиту і мають швидкий оборот капіталу. У зв'язку з цим необхідно підвищувати інвестиційну привабливість аграрних підприємств, де одним із таких засобів факторів впливу є створення інтегрованих формувань на основі кооперації, що дадуть можливість прискорити окупність вкладеного капіталу. Тому стосовно розвитку підприємницької діяльності в аграрному секторі дуже важливим є:

ких продуктів і високих технологій;

- організація інтегрованого сільськогосподарського виробництва, спроможного конкурувати 3 відомими вітчизняними та іноземними компаніями;

- $\quad$ створення і впровадження в аграрне виробництво перспективних урожайних сортів сільськогосподарських культур та високопродуктивних порід тварин;

- впровадження системи підтримки кредитування комерційними банками інноваційних проектів у підприємницьку діяльність в аграрному секторі;

- $\quad$ вдосконалення системи страхування у сільському господарстві;

- $\quad$ розширення кредитування інноваційних проектів за рахунок лізингових, факторингових та інших операцій.

Найчисельнішою організаційно-економічною формою підприємницької діяльності в сільському господарстві Львівської області є господарства населення. У них виробляється 70\% обсягу валової продукції сільського господарства. Питома вага сільськогосподарських підприємств і фермерських господарств у формуванні валового виробництва аграрної продукції залишається вкрай низькою. Характеристику їхніх сильних і слабких сторін наведено в табл. 4.

\section{Таблиця 4}

Характеристика сильних і слабких сторін основних організаційно-економічних форм підприємницької діяльності сільського господарства Львівської області*

\begin{tabular}{|c|c|c|c|}
\hline Ознака & Господарства населення & Аграрні підприємства & Фермерські господарства \\
\hline $\begin{array}{l}\text { Сильні } \\
\text { сторони }\end{array}$ & $\begin{array}{l}\text { - використання праці незайнятих } \\
\text {-пряма соціальна ефективність }\end{array}$ & $\begin{array}{l}\text { - переваги великомасштабного } \\
\text { виробництва } \\
\text { - спеціалізація виробництва }\end{array}$ & $\begin{array}{l}\text {-переваги невеликих підпри- } \\
\text { ємств } \\
\text {-малі трансакційні витрати }\end{array}$ \\
\hline $\begin{array}{l}\text { Слабкі } \\
\text { сторони }\end{array}$ & $\begin{array}{l}\text { - низька продуктивність праці } \\
\text {-несприйнятливість до новітніх } \\
\text { технологій }\end{array}$ & $\begin{array}{l}\text { - великі трансакційні витрати } \\
\text { - проблеми } 3 \text { мотивацією праці }\end{array}$ & $\begin{array}{l}\text {-нестача інвестицій } \\
\text {-обмежені можливості розвитку } \\
\text { тваринництва }\end{array}$ \\
\hline $\begin{array}{l}\text { Потенційні } \\
\text { можливості }\end{array}$ & $\begin{array}{l}\text { - виробництво екологічно чистої } \\
\text { продукції } \\
\text { - виробництво “під індивідуальне } \\
\text { замовлення” }\end{array}$ & $\begin{array}{l}\text { - зниження собівартості продукції } \\
\text { - підвищення конкурентоспро- } \\
\text { можності продукції }\end{array}$ & $\begin{array}{l}\text {-швидка реакція на зміни в } \\
\text { ринковій кон’юнктурі } \\
\text {-компактність виробництва }\end{array}$ \\
\hline $\begin{array}{l}\text { Загрози } \\
\text { (у } \\
\text { перспективі) } \\
\end{array}$ & $\begin{array}{l}\text {-зниження продуктивності праці } \\
\text {-неконкуренто-спроможність }\end{array}$ & $\begin{array}{l}\text { - ринкові зміни після вступу до } \\
\text { СОТ } \\
\text { - нестабільність цін }\end{array}$ & $\begin{array}{l}\text {-економічний тиск з боку вели- } \\
\text { ких підприємств } \\
\text { - суттєва залежність від кредитів }\end{array}$ \\
\hline
\end{tabular}

*Власні напрацювання автора 


\section{Висновки}

Запропоновані в статті шляхи вирішення проблем виробництва сільськогосподарської продукції зорієнтовані саме на європейські підходи до організації і функціонування продовольчого ринку. Окремі з них є вдалими орієнтирами для розробки подальшої стратегії розвитку підприємницької діяльності в сільському господарстві. Враховуючи взаємопов'язаність між собою учасників ринку аграрної продукції, однакову кінцеву мету їх функціонування, необхідний пошук взаємовигідних форм їхньої співпраці, які б могли при можливості аграрним виробникам уникати збитковості в підприємницькій діяльності та запобігати їй. 3 метою забезпечення ефективності вирощування свинини запропоновано створення районного інтегрованого підприємства, організаційну структуру якого утворюють виробничі, заготівельні та обслуговуючі кооперативи, підприємства із забою свиней та підприємства $з$ переробки свинини і виробництва з неї готової продукції, заклади оптової та фірмової торгівлі.

За своєю суттю такий вид вертикальної інтеграції являє собою об'єднання зусиль товаровиробників 3 вирощування свинини і переробників 3 метою просування у суміжні із сільськогосподарським виробництвом сфери діяльності для забезпечення контролю за рухом створеної у власному виробництві сільськогосподарської продукції та одержання від цього оптимального прибутку. Дані інтегровані угруповання покликані захистити інтереси сільськогосподарських товаровиробників у ринкових умовах, стати альтернативним шляхом розв'язання проблеми засилля посередницьких структур в агробізнесі та максимально підвищити їх ефективність і прибутковість.

Сучасна структура сільськогосподарського виробництва, співвідношення різних організаційноправових форм підприємницької діяльності склалася під впливом тих політичних, соціальних, економічних процесів, які відбувалися в умовах становлення незалежної держави. Зі зміною соціально-економічної ситуації виникла потреба у вдосконаленні виробничої структури сільського господарства, стимулюванні розвитку сільськогосподарського підприємництва як основного чинника підтримання продовольчої безпеки країни.

Отже, розвиток підприємницької діяльності сільського господарства базується на аналізі, оцінці сильних та слабких сторін, тобто методології системноцільового підходу, де основна увага акцентується на вимірі параметрів зовнішнього й внутрішнього середовища в просторі, у часі й з урахуванням інформаційного потенціалу.

\section{References}

Amosov, O.Yu. (2008). Fermerstvo yak forma pidpryiemnytstva $\mathrm{v}$ ahrarnii sferi. Ahrosvit, 8, 46-51 (in Ukrainian).

Andriichuk, V.H. (2005). Efektyvnist diialnosti ahrarnykh pidpryiemstv: teoriia, metodyka, analiz. K. KNEU (in Ukrainian).

Berezin, O. (2012). Suchasni ahrarni problemy ta yikh vplyv na rozvytok natsionalnoho prodovolchoho rynku Ukrainy. Naukovo-informatsiinyi visnyk Akademii nauk vyshchoi osvity Ukrainy, 2(79), 113123 (in Ukrainian).

Berezivskyi, P.S. (1999). Formuvannia bahatoukladnosti v silskomu hospodarstvi. Sotsialno-ekonomichna sytuatsiia ta shliakhy podolannia kryzovoho stanu $\mathrm{v}$ ahropromyslovomu kompleksi Ukrainy. K. IAE, 233238 (in Ukrainian).

Bitter, O.A., Berezivskyi, P.S., \& Melnyk, V.P. (1997). Efektyvnist silskohospodarskoho vyrobnytstva i riven zhyttia silskoho naselennia. Lviv. Ukrainski tekhnolohii (in Ukrainian).

Mesel-Veseliak, V.Ya. (2004). Rozvytok ta efektyvnist orhanizatsiino-pravovykh form hospodariuvannia $\mathrm{V}$ silskomu hospodarstvi Ukrainy. Ekonomika APK, 11, 20-81 (in Ukrainian).

Onyshchenko, O. (2004). Zrushennia v orhanizatsiinii strukturi silskohospodarskykh pidpryiemstv. Ekonomika Ukrainy, 11, 58-65 (in Ukrainian).

Sabluk, P.T. (2000). Ahrarna reforma: stan i napriamy rozvytku. Ekonomika APK, 4, 3-10 (in Ukrainian).

Shmorhun, L. (1999). Pro porivnialnu otsinku efektyvnosti form hospodariuvannia. Sotsialno-ekonomichna sytuatsiia ta shliakhy podolannia kryzovoho stanu $\mathrm{V}$ ahropromyslovomu kompleksi Ukrainy: Tezy vystupiv uchasnykiv vseukrainskykh zboriv vchenykh ekonomistiv-ahrarnykiv, Kyiv, 14-15 sichnia 1999 r. K. IAE, 230-233 (in Ukrainian).

Smolynets, I.B. (2013). Upravlinnia hospodarskym formuvanniam APK u konteksti prohramuvannia yoho finansovo-ekonomichnoi stiikosti. Naukovyi visnyk Lvivskoho natsionalnoho universytetu veterynarnoi medytsyny ta biotekhnolohii imeni S.Z. Gzhytskoho. Lviv. 15, 1(55), 186-207 (in Ukrainian).

Smolynets, I.B. (2014). Formuvannia orhanizatsiinoekonomichnykh vidnosyn pidpryiemstv APK v umovakh transformatsiinykh protsesiv. Zbirnyk naukovykh prats Krymskoho ahrotekhnichnoho universytetu. Simferopol, 159, 360-366 (in Ukrainian).

Yermakov, O. (2003). Metodolohiia ekonomichnoho doslidzhennia orhanizatsiinykh form vyrobnytstva. Ekonomika APK, 1, 31-37 (in Ukrainian). 